\title{
Kümes Hayvanlarının Beslenmesinde Antibiyotiklere Alternatif Olarak Nane (Mentha piperita L.) Kullanmanın Etkileri
}

\author{
Mehmet ÇETIN ${ }^{1 *}$ \\ ${ }^{1}$ Harran Üniversitesi Ziraat Fakültesi Zootekni Bölümü, Osmanbey Kampüsü, 63300-Şanlıurfa \\ *Sorumlu yazar: mehmetcetin63@harran.edu.tr
}

Öz

Kümes hayvanlarının beslemesinde verimliliği arttırmak için antibiyotiklere alternatif olabilecek yem katkı maddeleri arayışı devam etmektedir. Yapılan araştırmalar tıbbi ve aromatik bitkilerin zararlı mikroorganizmaların sindirim sistemine yerleşmesini engelleyerek sindirimi arttırdığı, bağışıklık sistemini güçlendirdiği, yemin lezzetini artıırarak yem tüketimini ve yemden yararlanmayı artıırdığını, dolayısıyla hayvanlarda performansı olumlu etkilediğini ve kanatlı beslenmesinde antibiyotiklere alternatif olarak kullanılabileceğini göstermektedir. Bu derlemede tıbbi aromatik bir bitki olan nanenin alternatif yem katkı maddesi olarak kullanılması hakkında bilgi verilecektir.

Anahtar kelimeler: Kanatlı hayvanlar, Nane, Antibiyotik, Alternatif yem katkı maddeleri

\section{The Effects of Use Peppermint (Mentha piperita L.) as Alternative to Antibiotics in Poultry Nutrition}

\section{Abstract}

It has been searching to continuous feed additives alternative to antibiotics to increase productivity in poultry nutrition. Researches show that the medicinal and aromatic plants increase the digestion system and the immune system by preventing the settlement of harmful microorganisms in the digestive system. Moreover, this type of plants used as feed additive increased feed conversation ratio, performance and feed intake. As a result, medical plants seem to be an alternative to antibiotics because of their positive effects in performance of poultry nutrition. In this review, peppermint as medical herbs was evaluated as an alternative feed additive material.

Keywords: Poultry, Peppermint, Antibiotics, Feed additive

Giriş

Dünya nüfusunun hızla artmasıyla birlikte besin maddelerine olan ihtiyaç da arttırmaktadır. Bu doğrultuda besin madde üreticileri daha fazla ürün elde etmek için adeta yarışmakta ve bu yarış bazen tüketicilerin sağlığını risk edebilmektedir.

Yem değerlendirme oranını iyileştirmek, ürün tat ve aromasını geliştirmek ve sağlık koruma amacı ile yemlere katılan katkı maddeleri üründe istenmeyen kalıntı bırakabilmektedir. Ürünlerde görülen kalıntının insan sağığına olumsuz etkilerinden dolayı, 2006 yılından beri Dünya Sağlık Örgütü (WHO) hayvan yemlerinde antibiyotik kullanımasını yasaklamıştır. Yapılan çalışmalarda, kümes hayvanlarının yemlerinde kullanılan antibiyotik ve antikoksidiyallere karşı deney hayvanlarının direncini arttırdığı bildirilmiştir. Bunun sonucu olarak insan sağlığına zararlı etkisi olmayacak antibiyotiklere ve diğer kimyasal yem katkı maddelerine alternatif olarak tıbbi 
ve aromatik bitkilerin kullanımı ön plana çıkmıştır. Yapılan çalışmalardaki amaç antibiyotik ve antikoksidiyal gibi yem katkı maddelerinin olumsuz etkilerini ortadan kaldırmak, yemden yararlanma oranı, canlı ağırlı artışını sağlamak ve kanatlı hayvanları patojen mikroorganizmalara karşı korumaktır (Çetin, 2008; Çiçek ve ark., 2010).

Türkiye tıbbi ve aromatik bitkiler bakımından oldukça zengin bir yapıya sahiptir. Bu bitkiler içerdikleri etken maddelere göre antioksidan, antienflamatuar, antiallerjen, antidepresif ve antimikrobiyal etki gösterebilmektedir (Buğdaycl, 2008; Salih ve Gürbüz, 2015). Ayrıca bu bitkiler, doğal olduğundan tüketiciler tarafından büyük bir ilgi görmekte, bağışıklık sistemini uyarıcı, yem tüketimini teşvik edici, yemden yararlanmayı arttırıcı, sindirime yardımcı ve performans arttırıcı özelliklerinden dolayı tercih edilmektedir (Kutlu ve Erdoğan, 2010).

Yapılan çalışmalar, kekik (Thymus vulgaris), adaçayı (Salvia), defne (Laurus), karanfil (Syzygium), kişniş (Coriandrum sativum), nane (Mentha piperita), hindistan cevizi (Cocos nucifera), tarçın (Cinnamomum), kimyon (Cuminum cyminum), anason (Pimpinella anisum), biberiye (Rosmarinus officinalis L.), karabiber (Piper nigrum), sarımsak (Allium sativum), zencefil (Zingiber officinale) ve kereviz (Apium graveolens) gibi aromatik bitkiler ve bunlardan elde edilen extraktların antimikrobiyal etkiye sahip olduğunu ve hayvanlarda performansı olumlu etkilediğini, dolayısıyla antibiyotiklerin yerine yem katkı maddesi olarak kullanılabileceğini göstermektedir (Güler ve Dalkılıç, 2005).

\section{Tıbbi ve Aromatik Bitkilerin Etki Mekanizması}

Tıbbi ve aromatik bitkilerden elde edilen uçucu yağ ve ekstraktlar hastalık etmeni mikroorganizmaların sindirim sistemine yerleşmelerini engelleyerek, sindirim enzimlerinin etkilerini arttırdığı, bağışıklık sistemini güçlendirdiği ve yemden yararlanmayı arttırdığı belirtilmiştir (Jamroz ve ark., 2003).

Tıbbi ve aromatik bitkilerde bulunan antioksidan maddeler serbest radikallerin olumsuz etkilerini bertaraf etmektedir (Karasu ve Öztürk, 2014).

Hatalı beslenme veya stres durumunda ortaya çıkan serbest radikallerin etkisinin savunma sistemi ile önlenemediği durumlarda oksidatif stres meydana gelmektedir. Oksidatif stres dejeneratif bozukluklara, performans kaybına, ürün kalitesinde düşmeye neden olabilmektedir. Kanatı hayvan rasyonlarına ilave edilecek doğal ve sentetik antioksidan maddelerin bu olumsuzlukları azaltması yada ortadan kaldırması mümkün görülmektedir (Çelik ve ark., 2010).

\section{Nanenin Kanatı Hayvan Beslemede Kullanımı}

Doğal antioksidanlara artan ilgi, alternatif bitkileri araştırmak konusunda bilim adamlarını teşvik etmektedir. Antioksidan maddeler, okside olabilen gıdaların bozulmasını önlemek için geniş ölçüde gerekmektedir. $\mathrm{Bu}$ maddelerin antikanserojenik, antimutajenik, antiallerjik ve yaşlanmayı geciktirici biyolojik özelliklere sahip olduğu belirtilmiştir (Moure ve ark., 2001).

Bakteri ve kanser hücrelerini bloke eden bitkisel ilaçlar yeni bir tedavi şekli sunmaktadır. Bu ilaçlar potansiyel olarak kanseri önlemeye yardımcı olabilmektedir (Yarnell ve Abascal, 2008).

Etlik piliçlerde büyümeyi teşvik için kontrol, $5 \mathrm{mg} \mathrm{kg}^{-1}$ virginiamycin, $\%$ 0, 0.1, 0.2, 0.3 nane (Mentha piperita) etanol ekstraktı içme suyuna katıldığında \% 0.2 ve 0.3 nane 
etanol ekstraktı verilen grupta diğer gruplara göre karkas verimi artmış, abdominal yağ miktarı azalmıştır $(P<0.05)$ (Nanekarani ve ark., 2012).

Etlik piliçlere kontrol, 2 ve $4 \mathrm{~g} \mathrm{~kg}^{-1}$ çörek otu (Nigella sativa), 4 ve $8 \mathrm{~g} \mathrm{~kg}^{-1}$ nane (Mentha piperita) bazal rasyona ilave edildiğinde, 0-42 günlerde en iyi yemden yararlanma oranı $4 \mathrm{~g} \mathrm{~kg}^{-1}$ çörek otu yedirilen grupta görülmüş $(\mathrm{P}<0.05)$. Çörek otu ilavesi 42 günde lenf organlarının ağırlığında belirgin bir artışa $(P<0.05)$ neden olmuştur. Serum protein, albümin, trigliserit, LDL, HDL ve total kolesterol gibi biyokimyasal parametreler, serum glutamik-oksoloasetik transaminaz (SGOT) ve serum glutamikprüvik transaminaz (SGPT) enzim konsantrasyonu muameleden etkilenmemiş. But eti duyusal olarak değerlendirildiğinde, koku ve lezzet bakımından anormal bir durum görülmemiştir (Toghyani ve ark., 2010).

Etlik piliçlerde büyümeyi teşvik için \%0.2 kurutulmuş nane (Mentha piperita L.) ve kekik (Thymus vulgaris L.) yaprakları veya 70 $\mathrm{mg} \mathrm{kg}^{-1}$ mentol (menthol) ya da timol (thymol) olarak rasyona ilave edildiğinde 735 günlerde en yüksek canlı ağırlık artışı nane ilave edilen grupta gerçekleşmiş fakat 42 günlük yaşta bu etki ortadan kalkmıştır. Yem tüketimi, yemden yararlanma oranı, karkas ağırlığı, karkas verimi, yenilebilir iç organların oranı, tüm bağırsak ve tüm bağırsağın oranı nane ve kekik içeriğinden etkilenmemiş. Nane ve kekik yaprakları 42 günlük yaşta abdominal yağ miktarını arttırmıştır $(P<0.05)$. Piliç büyütme döneminde nane yaprakları, kekik yapraklarından daha fazla gelişmeyi teşvik etmiş, ancak abdominal yağ miktarını da arttırmıştır (Ocak ve ark., 2008).

Erkek piliç rasyonlarına nane (Mentha piperita) esansiyel yağı, antibiyotik (Virginiamycine) ve Fruktomix (Topinambour:
Jerusalem artichoke; Helianthus tuberosus) ilave ederek büyüme performansı, sindirilebilirlik, bağırsak morfolojisi ve immun sistem üzerine etkilerini araştırmışlar. Kontrol, $200 \mathrm{mg} \mathrm{kg}^{-1}$ Virginiamycin, $200 \mathrm{mg}$ $\mathrm{kg}^{-1}$ nane esansiyel yağı, $400 \mathrm{mg} \mathrm{kg}^{-1}$ nane esansiyel yağı ve $500 \mathrm{mg} \mathrm{kg}^{-1}$ Fruktomix grupları karşılaştırıldığında 42 günün sonunda en yüksek canlı ağırlık artışı ve yem tüketimi, Virginiamycin verilen grupta elde edilmiş $(P<0.001)$, en iyi yemden yararlanma oranı Virginiamycin ve nane esansiyel yağı verilen grupta (sırasıyla, 1.74, 1.75) elde edilmiştir ( $P=0.039)$ (Emami ve ark., 2012).

Etlik piliç rasyonlarına nane (menthol) ilavesinin kontrol grubuna göre canlı ağırlık artışını düşürdüğü, kekik yağı (karvakrol) ilavesinin ise kontrol grubuyla aynı olduğu belirtilmiştir (Erener ve ark., 2005).

Etlik piliçlerde nane (Mentha piperita) ve fesleğen (Ocimum basilicum) bitkisinin etkisinin araştırmak için kontrol, \%0.5, \%1, \%1.5 nane, \%0.5, \%1, \%1.5 fesleğen kontrol rasyonuna ilaveten kullanılmış. (Sırasıyla gruplar T1, T2, T3, T4, T5, T6 ve T7 olarak ifade edilmiştir). En yüksek canlı ağırlık $T 1$, $T 2, T 3, T 5$ gruplarında $(P \leq 0.05)$, en düşük canlı ağırlık ise T4 grubunda gözlenmiştir. Yem tüketimi T4 hariç diğer gruplarda önemli derecede $(P \leq 0.05)$ yüksek görülmüş. T6 ve T7 gruplarında yemden yararlanma oranı önemli derecede yüksek $(P \leq 0.05)$ bulunmuş. T5'te en yüksek karaciğer ağırlığı elde edilmiş $(P \leq 0.05)$. Karkas verimi ve abdominal yağ bakımından gruplar arasında önemli bir fark görülmemiştir. Nane ve fesleğenin piliçlerin performansına önemli bir etkisi olmamış, ancak zararlı bir etkisi de görülmemiştir. Yine de piliçleri nane ile beslemek kontrole göre büyüme performansını olumlu etkilemiş. Etlik piliçlerin üretiminde büyümeyi teşvik için rasyona nane ilavesinin antibiyotiklere 
alternatif olabileceği belirtilmiştir (Gürbüz ve ismael, 2015).

Etlik piliçlerde kurutulmuş nane (Mentha cordifolia) $\% 0,0.5,1,1.5$ ve 2 oranında rasyona ilave edilmiştir. Nane ilavesinin kuru madde, organik madde, ham sellüloz ve nitrojen kalıntısı üzerine önemli bir etkisi olmazken dışkıda önemli $(P \leq 0.05)$ düzeyde amonyak azalması görülmüş. Ayrıca deney 2 'de kontrol, kontrol rasyonuna ilaveten 5 ppm klortetrasiklin, \% 0.5, 1, 1.5 ve 2 nane tüketen piliçler karşılaştırıldığında piliçlerin büyüme performansı ve karkas özelliklerine herhangi bir etkisinin olmadığı, fakat tüm nane seviyelerinde ürün indekslerinin arttığı ve abdominal yağın azaldığı görülmüştür. Ancak antioksidan aktivitesi, abdominal yağ depolanması ve amonyak üretimi üzerine faydalı etkileri görülmüştür (Khempaka ve ark., 2013).

Sıcaklık stresi altında yetiştirilen etlik piliçlerde kontrol, $1 \mathrm{mg} \mathrm{kg}^{-1}$ chromium picolinate (CrPic) ve $250 \mathrm{mg} \mathrm{kg}^{-1}$ nane (Mentha piperita) esansiyel yağı rasyona ilave edildiğinde canlı ağırlığı etkilememiş, yemden yararlanma oranı her iki muamelede önemli derecede azalmış, keza serum trigliserit ve glukoz konsantrasyonları önemli derecede $(\mathrm{P}<0.05)$ azalmıştır (Akbari ve Torki, 2014).

Etlik piliç rasyonlarına kontrol, kontrole ilaveten 200 ppm virginiamycine, \%0.4 nane yaprağı, \%0.4 tarragon (Artemisia drancunculus) yaprağı, \%0.2 nane $+\% 0.2$ tarragon yaprağı katıldığında ortalama canlı ağırlık, canlı ağırlık artışı, yem tüketimi ve yemden yararlanma oranı muameleden etkilenmemiştir. Kontrol, bitki veya antibiyotik gruplarında kesim özellikleri bakımından önemli bir fark görülmemiştir (Gharetappe ve ark., 2015).

Etlik piliç rasyonlarına sırasıyla 15, 3, 2, 2 $\mathrm{g} \mathrm{kg}^{-1}$ kimyon (Cuminum cyminum), nane
(Mentha piperita), civanperçemi (Achillea millefolium) ve tüylü kısamahmut (Teucrium polium) konulmuş. Tıbbi bitki veya antibiyotik içermeyen negatif kontrol, $0.4 \mathrm{~g}$ $\mathrm{kg}^{-1}$ flavomycin içeren pozitif kontrol kullanılmış. Flavomycin ve nane içeren gruplarda kontrole göre yem tüketimi ve canlı ağırlık önemli derecede $(P<0.01)$ artmıştır. Nane ve kimyon gruplarında canlı ağırlık artmış, negatif kontrol ile karşılaştırıldığında civanperçemi ve tüylü kısamahmut grubunda canlı ağırlık önemli derecede azalmış, yemden yararlanma oranı artmıştır $(\mathrm{P}<0.05)$. Flavomycin ve nane grubunda serum trigliserit, total kolesterol ve LDL kolesterol önemli düzeyde $(P<0.05)$ arttırmıştır. Büyümeyi teşvik için kanatlı rasyonlarında antibiyotiklere alternatif olarak nane kullanılabileceği belirtilmiştir (Sharifi ve ark., 2013).

Japon bıldırcın rasyonlarında negatif kontrol, subterapötik (terapiye yakın) miktarda antibiyotik (flavofosfolipol) bulunan pozitif kontrol, negatif kontrole ilaveten 10 , 20,30 ve $40 \mathrm{~g} \mathrm{~kg}^{-1}$ nane (Mentha piperita) eklenmiştir. 7-35. günlerde bıldırcın performansları muameleden etkilememiştir. Rasyona nane katılması ince bağırsak uzunluğunu, villus yüksekliği, villus genişliği, cript derinliği ve villus alanını lineer olarak arttırmıştır. Japon bıldırcın rasyonlarına 20$30 \mathrm{~g} \mathrm{~kg}^{-1}$ nane katılması bağırsak popülasyonu ve emilim yüzeyini arttırmak için antibiyotiklere alternatif olabileceği belirtilmiştir (Mehri ve ark., 2015).

Japon bıldırcınlarında rasyona antibiyotik (flavofosfolipol) içeren pozitif kontrol, antibiyotik bulunmayan negatif kontrol ve negatif kontrole ilaveten $10,20,30$ ve $40 \mathrm{~g}$ $\mathrm{kg}^{-1}$ nane (Mentha piperita) ilave edilerek serum biyokimyası, et kalitesi ve humoral bağışıklığa bakılmış. Nane tüketen bıldırcınlarda trigliserit, total kolesterol, LDL 
kolesterol ve ALT (alanine amino transferase) konsantrasyonu azalmış, HDL kolesterol seviyesi kontrole göre artmıştır $(P<0.001)$. Rasyona 20-30 $\mathrm{g} \mathrm{kg}^{-1}$ nane katılması kan profili, humoral bağışıklık sistemi ve et kalitesinin iyileşmesinde antibiyotiklere alternatif olabileceği belirtilmiştir (Mehri ve ark., 2015a).

Japon bıldırcınlarına kontrol, \%1.5 ve 3 nane (Mentha piperita) 42 gün yedirildiğinde canlı ağırlık, yem tüketimi ve yemden yararlanma oranı nane ilavesinden önemli derecede $(P<0.05)$ etkilenmiş. \%1.5 nane ile beslenen bıldırcınlarda kontrol ve $\% 3$ nane tüketenlere göre daha fazla göğüs eti oranı elde edilmiştir. \%1.5 nane tüketenlerde \%3 nane grubuna göre yemden yararlanma oranı önemli derecede $(P<0.05)$ artmış. Muamele grupları arasında zayıf kas ve karkas yüzdesi arasındaki fark önemsiz çıkmış. Japon bıldırcınlarında farklı seviyelerde nane kullanımı ile yemden yararlanma oranı iyileşmiş ve canlı ağırlık artmıştır (Aminzade ve ark., 2012a).

Japon bıldırcınlarına $\% 0,1.5$ ve 3 nane (Mentha piperita) bitkisi yedirildiğinde kesilen bıldırcınlar $2-4^{\circ} \mathrm{C}^{\prime}$ de 24 saat bekletilmiş. Bıldırcın etlerinde sarılık, kırmızlık ve TBARS (Thiobarbituric acidreacting substances) nane içeren rasyonlardan önemli derecede $(P<0.05)$ etkilenmiş, parlaklık, su tutma kapasitesi (WHC), asitlik (pH) ve kas içerisi yağ (IMF) bakımından gruplar arasında önemli bir fark görülmemiştir (Aminzade ve ark., 2012b).

45 haftalık yaşta 192 adet Isa Brown yumurta tavuğu rasyonlarına kontrol, \%1 ve \%1.5 karışık bitki ekstraktı (papatya, kekik, nane, ısırgan otu, at kuyruğu, çayır düğmesi, karaman kimyonu, kişniş tohumu, zambak kökü) (Anthemis, Thymus, Minth, Urtica, Equisetum, Sanguisorba, Carum carvi, Coriandrum seed, Lilium root) ilave edildiğinde yumurta verimini etkilemediği ancak yumurtlama periyodu sonunda yumurta sarı renginde önemli oranda koyulaştığı, 1, 2 ve 3 . grupta $1 \mathrm{~g}$ yumurta sarısında toplam kolesterol içeriğinin sırasıyla $14.44,13.54$ ve $13.91 \mathrm{mg} \mathrm{g}^{-1}$ olduğu, yumurta kabuk kalitesi ve iç kalite özellikleri bakımından gruplar arasında herhangi bir fark görülmediği belirtilmiştir (Poltowicz ve Wezyk, 2001).

Hy-Line Brown yumurta tavuklarında yumurtlama periyodunun sonunda (64-76 hafta) rasyona $0,5,10,15,20 \mathrm{~g} \mathrm{~kg}^{-1}$ kuru nane yaprağı (Mentha piperita L.) ilave edilmiş. Yumurta ağırlığı, yumurta üretimi, yumurta büyüklüğü ve yem tüketimi $64-68$, 68-72, 72-76 haftalarda önemli derecede (Lineer $\mathrm{P}<0.001$ ) artmış. Yemden yararlanma oranı rasyonda nane oranının artmasıyla lineer olarak $(P<0.001)$ azalmış. En iyi performans nane rasyonlarında görülmüş. Nane yaprakları ilave edilen rasyonları tüketen tavukların yumurta kabuk yüzdesi, kabuk kalınlığı ve haugh birimi kontrol grubundan daha yüksek $(P<0.01)$ gerçekleşmiş. Nane ilavesi yumurta akı, yumurta sarı yüzdesi ve yumurta akı yüksekliği gibi özellikleri etkilememiş, serum kolesterol düzeyi önemli derecede $(P<0.001)$ azalmış, nane oranının artmasıyla serum proteinleri artmıştır $(P=0.015)$. Nane yaprakları yumurtlama peryodunun sonunda performansı iyileştirmek için etkili bir yem katkısı olabileceği belirtilmiştir (AbdelWareth ve Lohakare, 2014).

\section{Nanenin Balık Beslemede Kullanımı}

Yavru Hazar Beyaz Balı̆̆ı'nın (Rutilus frisii kutum) büyüme performansı, kimyasal vücut kompozisyonu, hematoloji ve immun parametreleri üzerine $\% 0,1,2,3$ diyetsel nane (Mentha piperita) ekstraktı 8 hafta süreyle rasyona ilave edildiğinde doza bağlı 
olarak ağılık artışının olduğu görülmüştür (Adel ve ark., 2015).

Balık rasyonlarına \%0, 1, 2, 3, 4, $5 \mathrm{~g} \mathrm{~kg}^{-1}$ nane konulduğunda mortalitenin azaldığı, yaşama gücü, ağırlık artışı ve yemden yararlanma oranının önemli derecede iyileştiği görülmüştür. Nane (Mentha piperita) verilen balıklarda eritrosit, lökosit, hematoktit, hemoglobin, fagositik aktivite, solunum oranı, lisozim, antiproteaz ve bakterisidal aktivite ayrıca serum protein ve globulin düzeyleri önemli derecede artmış, glukoz, lipit, trigliserit ve kolesterol seviyelerinde azalma görülmüştür. Balık beslemede antibiyotik veya güçlendirilmiş su kültürünü terapötik amaçla kullanmak yerine nane kullanıbilir (Allah, 2014).

\section{Sonuç}

Araştırmaların sonuçlarında; kanatlı hayvanlarda alternatif olarak kullanılan tıbbi aromatik bitkilerin yaşama gücü, yem değerlendirme oranı, yumurta ve kan kolesterol seviyesinin azaltılması canlı ağırık artışı, bağışıkık sisteminde yapmış olduğu olumlu sonuçlar, sindirim sistemindeki patojen mikroorganizmaların azaltılması, karkas kalitesindeki olumlu gelişmeler ve yumurtanın iç ve dış kalitesine yaptığı pozitif veriler ortaya çıkmıştır. Tıbbi aromatik bitki olan nane ile yapılan çalışmalarda, farkı oranlarda kanatı hayvanların beslenmesinde antibiyotiklere alternatif olarak kullanılabileceğini göstermektedir. Ancak hangi kanatlı hayvanlarda hangi rasyon bileşiminde ve hangi oranda rasyona ilave edilmesi ile ilgili çalışmaların daha kontrollü ve sahada uygulanabilecek şekilde çalışılması gerekmektedir. Antibiyotik gibi uzun süre içinde bağışıklık kazanan ve üründe insan sağlığına zarar verici özellik gösteren kimyasal yem katkı maddeleri yerine çiftlik hayvanlarının rasyonunda kullanılmasında gerekli hassasiyetin gösterilmesi gerekir. Aksi halde içerdiği fenolik ve antibesinsel maddeler istenilen sonuçların alınmasında önemli bir engel olabilecektir. Bunun için tıbbi ve aromatik bitkilerin her zaman optimum rasyona katılım oranlarının tespit edilerek, hayvan beslemede kullanılması önem arz etmektedir.

\section{Kaynaklar}

Abdel-Wareth, A.A.A., Lohakare, J.D., 2014. Effect of dietary supplementation of peppermint onperformance, egg quality, and serum metabolic profile of Hy-Line Brown hens during the late laying period. Animal Feed Science and Technology, 197: 114-120.

Adel, M., Amiri, A.A., Zorriehzahra, J., Nematolahi, A., Esteban, M.A. 2015. Effects of dietary peppermint (Mentha piperita) on growth performance, chemical body composition and hematological and immune parameters of fry Caspian white fish (Rutilus frisii kutum). Fish Shellfish Immunology, 45: 841-847.

Akbari, M., Torki, M., 2014. Effects of dietary chromium picolinate and peppermint essential oil on growth performance and blood biochemical parameters of broiler chicks reared under heat stress conditions. International Journal of Biometeorology, 58 (6): 1383-1389.

Allah, D.T., 2014. Mentha piperita (Peppermint) as feed additive enhanced growth performance, survival, immune response and disease resistance of Asian seabass, Lates calcarifer (Bloch) against Vibrio harveyi infection. Aquaculture, 420-421: 71-78

Aminzade, B., Karami, B., Lotfi, E., 2012a. Meat quality characteristics in Japanese quails fed with Mentha piperita plant. International Journal of the Bioflux Society, 4(1): 20-23.

Aminzade, B., Karami, B., Lotfi, E., 2012b. Growth response and carcass characteristics of Japanese quail to Mentha piperita plant supplementation. International Journal of the Bioflux Society, 4(1): 24-27.

Buğdaycl, K. E., 2008. Esansiyel Yağ ve Probiyotiğin Broylerde Performans, İmmun Sistem ve Bazı Kan Parametreleri 
Üzerine Etkisi. Doktora Tezi, Ankara Üniversitesi Sağlık Bilimleri Enstitüsü, Ankara, 89s.

Çelik, L., Serbester, U., Kutlu, H.R., 2010. Kanatlı Hayvanlarda Oksidatif Stres Oluşumu ve Önleme. Kümes Hayvanları Kongresi, 0709 Ekim, Kayseri.

Çetin, T., 2008. Eterik Yağların Broylerde Besi Performansı, Bazı Kan Parametreleri ile Newcastle Hastalığı ve Infeksiyöz Bronşitis Antikor Seviyeleri Üzerine Etkisi. Doktora Tezi, Ankara Üniversitesi Sağlık Bilimleri Enstitüsü, Ankara, 86s.

Çiçek, R.T., Gökmen, C., Gürbüz, Y., 2010. Effect of watercress (Nasturtium officinale R.Br.) on egg quality, yolk colour and yolk fatty acit composition in laying hens. Arch Geflügelk, 74 (3) 178-182.

Emami, N.K., Samie, A., Rahmani, H.R., Ruiz-Feria, C.AS., 2012. The effect of peppermint essential oil and fructooligosaccharides, as alternatives to virginiamycin, on growth performance, digestibility, gut morphology and immune response of male broilers. Animal Feed Science and Technology, 175: 57-64.

Erener, G., Ocak, N., Ak, F.B., Altop, A., 2005. Nane (mentol) veya kekik (karvakrol) esans yağı ilave edilen karmalar ile yemlenen etlik piliçlerin performansları. III. Ulusal Hayvan Besleme Kongresi, 7-10 Eylül, Adana, s.58-62

Gharetappe, F. K., Hassanabadi, A., Semnaninezhad, H., Nassiry, M. R., 2015. The Effect of Dietary Tarragon (Artemisia dracunculus) and Peppermint (Mentha piperita) Leaves on Growth Performance and Antibody Response of Broiler Chickens. Iranian Journal of Applied Animal Science, 5 (2): 403-409.

Güler, T., Dalkılıç, B., 2005. Aromatik Bitkilerin Organik (Ekolojik) Hayvancılıkta Kullanım İmkânı. Doğu Anadolu Bölgesi Araştırmaları, Elazığ

Gürbüz, Y., İsmael, I. A., 2015. Effect of Peppermint and Basil as Feed Additive on Broiler Performance and Carcass Characteristics. Iranian Journal of Applied Animal Science, 6(1): 149-156.

Jamroz, D., Orda, J., Kamel C., Wiliczkiewicz, A., Wertelecki, T., Skorupinska, J., 2003. The influence of phytogenetic extracts on performance, nutrient 18 digestibility, carcass charactristics, and gut microbial status in broiler chickens, J. Anim. Feed Sci., 12: 583-596.

Karasu, K., Öztürk, E., 2014. Tıbbi ve aromatik bitkilerinkanatlılarda antioksidan ve antimikrobiyal etkileri. Turkish Journal of Agricultural and Natural Sciences. Special Issue: 2 (www.turkjans.com)

Khempaka, S., Pudpila, U., Molee, W., 2013. Effect of dried peppermint (Mentha cordifolia) on growth performance, nutrient digestibility, carcass traits, antioxidant properties, and ammonia production in broilers. J. Appl. Poult. Res., 22: 904-912.

Kutlu, T., Erdoğan, Z., 2010. Kanatlı Beslemede Fitobiyotik Yem Katkı Maddeleri. 1. Ulusal Kümes Hayvanları Kongresi, 7-9 Ekim, Kayseri. 13s.

Moure, A., Cruz, J.M., Franco, D., Dominguez, J.M., Sineiro, J., Dominguez, H., Nunez, M.J., Parajo, J.C., 2001. Natural antioxidants from residual sources. Review. Food Chemistry, 72: 145-171.

Mehri, M., Sabaghi, V., Bagherzadeh-Kasmani, F., 2015a. Mentha piperita (peppermint) in growing Japanese quails' diet Serum biochemistry, meat quality, humoral immunity. Animal Feed Science and Technology, 206: 57-66

Mehri, M., Sabaghi, V., Bagherzadeh-Kasmani, F., 2015b. Mentha piperita (peppermint) in growing Japanese quails diet Performance, carcass attributes, morphology and microbial populations of intestine. Animal Feed Science and Technology, 207: 104111.

Nanekarani, S., Goodarzi, M., Heidari, M., Landy, N., 2012. Efficiency of ethanolic extract of peppermint (Mentha piperita) as an antibiotic growth promoter substitution on performance, and carcass characteristics in broiler chickens. Asian Pasific Journal of Tropical Biomedicine, 2 (3):1611-1614.

Ocak, N., Erener, G., Ak, B.F., Sungu, M., Altop, A., Ozmen, A., 2008. Performance of broilers fed diets supplemented with dry peppermint (Mentha piperita) or thyme (Thymus vulgaris) leaves as growth promoter source. Czech J. Anim. Sci., 53(4):169-175

Poltowicz, K., Wezyk, S., 2001. Effect of herb supplementation in the feding of laying henson their productivity and egg quality. 
Roczniki Naukovve Zootechniki, 28 (2): 215-225.

Salih, Y.G., Gürbüz, Y., 2015. Sumac (Rhus coriaria L.) and Ginger (Zingiber officinale) as Feed additive in Poultry Nutrition., KSU J. Nat. Sci., 18 (3), 2015, P: 44-48

Sharifi, S.D., Khorsandi, S.H., Khadem, A.A., Salehi, A., Moslehi, H., 2013. The effect of four medicinal plants on the performance, bloodbiochemical traits and ileal microfl ora of broiler chicks. Veterınarskı Arhıv, 83(1): 69-80.

Toghyani, M., Toghayani, M., Gheisari, A., Ghalamkari, G., Mohammadrezaei, M., 2010. Growth performance, serum biochemistry and blood hematology of broiler chicks fed different levels of black seed (Nigella sativa) and peppermint (Mentha piperita). Livestck Science, 129: 173-178.

Yarnell, E., Abascal, K., 2008. Antiadhesion Herbs. Alternative \& Complementary Therapie, 14 (3):139-14. 